\title{
PARADICSOM FAJTATÍPUSOK FOTOSZINTÉZIS INTENZITÁSÁNAK ÖSSZEHASONLÍTÓ VIZSGÁLATA
}

\author{
Tóthné Taskovics Zs. ${ }^{1 *}$-Palkovics $A .{ }^{1}$-Váradi Gy. ${ }^{2}$-Magyar Á. ${ }^{3}$-Kovács $A .{ }^{1}$ \\ ${ }^{1}$ Neumann János Egyetem, Kertészeti és Vidékfejlesztési Kar, Kecskemét \\ ${ }_{2}^{2}$ Magyar Agrár- és Élettudományi Egyetem Kertészettudományi Intézet, Budapest \\ ${ }^{3}$ Árpád Agrár Zrt, Szegvár \\ https://doi.org/10.47833/2021.1.AGR.007
}

\section{Kulcsszavak: \\ fotoszintézis \\ paradicsom \\ sztóma konduktancia \\ fényválasz görbe}

\section{Keywords:}

photosynthesis

tomato

stoma conductance

light response curve

\section{Cikktörténet:}

Beérkezett 2021. március 10.

Átdolgozva 2021. március 20.

Elfogadva 2021. április 5.

\begin{abstract}
Összefoglalás
Fotoszintézis vizsgálatot végeztünk hajtatott paradicsomnál eltérö fajtatípusok esetében. Kétféle snack paradicsom fajtát hasonlítottunk össze egy nagybogyójú fajtával, korszerü üvegházi körülmények között, kókuszrost paplanokon termesztett növényeknél, 12 hónapos kultúrában. A méréseket Walz gyártmányú GFS-3000-es müszerrel végeztük, mindhárom fajtánál fényválasz görbét vettünk fel. Emellett a két snack fajtánál két héten keresztül folyamatos méréseket is végeztünk PTM-50-es automata fotoszintézis mérövel.

A két snack fajtánál a fotoszintetikus teljesítményben 15-30\%-os különbség mutatkozott. A nagy bogyójú fajta viszont ehhez képest kb. 230\%-kal nagyobb értéket adott. Ezek az adatok tendenciájukban szoros kapcsolatot mutatnak a leszedett termésmennyiséggel.
\end{abstract}

\begin{abstract}
Our photosynthesis study was performed on forced tomatoes for different cultivar types. Two types of snack tomatoes were compared with one large-berry variety under modern greenhouse conditions, on plants grown on coconut fiber quilts in a 12-month culture. Measurements were performed with a Walz GFS-3000 instrument, and light response curves were recorded for all three varieties. In addition, continuous measurements of the two snack varieties were performed for two weeks with a PTM-50 automatic photosynthesis meter.

We showed a $15-30 \%$ difference in the photosynthetic activity between the two snack types. The large berry variety, on the other hand, gave a value of about $230 \%$ higher. These data tend to be closely related to the harvested amount of the fruits.
\end{abstract}

\section{Bevezetés}

A növények termőképességét alapvetően az elsődleges anyagcsere folyamatok és ezen belül is döntöen a fotoszintézis teljesítménye határozza meg [2,5,10,11,12]. A zöldségnövények esetében a nemesítés során a szelekció egyik fontos szempontja a nagyobb termőképesség elérése. A termőképesség jól mérhető többéves terméseredmények értékelésével, de jó lenne olyan korszerü

\footnotetext{
* Kapcsolattartó szerző. Tel.: +3676516-311

E-mail cím: tothne.zsuzsanna@kvk.uni-neumann.hu
} 
mérésitechnika is, amellyel hatékonyabban, rövidebb idő alatt és a különféle környezeti tényezők hatásának hatékony vizsgálatával felgyorsíthatnánk ezt a folyamatot. Az ilyen mérések egzaktabbá és tudományosan megalapozottabbá tehetnék a nemesítők munkáját [9]. Ezen túlmenően,a fotoszintetikus folyamatok hatékonyságának mérésén keresztül a különféle stresszhatásokkal szembeni tűrőképesség is jól vizsgálható és bemutatható lenne modell kísérletekben [4,6 7].

A világon a legnagyobb felületen hajtatott zöldségfaj a paradicsom. Magyarországon a második legnagyobb felületen hajtatott zöldség faj kb.350 ha-ral. A növények egyik legfontosabb élettani mutatója a fotoszintézis tevékenysége. Számtalan kezelés hatását szokták fény válaszgörbével és a nettó fotoszintézis, valamint a párologtatás sebességének mérésével is detektálni [1,3,4 ]. Az ilyen méréseket általában kifejlett levélen, de előfordul, hogy teljes növényen is végzik [8].

Az egyik legelterjedtebben alkalmazott méréstechnika, amellyel a fotoszintetikus teljesítmény és a stressztürés vizsgálható, az infravörös gázelemzőkre alapozott levél gázcsere mérés. Ennek segítségével nyomon követhetjük a nettó fotoszintézis és a párologtatás sebességének alakulását, valamint a gázcsere folyamatok szabályozásában kulcsszerepet játszó levél légzőnyilások (sztómák) müködését, szabályozott növénykörnyezetben, biotikus vagy abiotikus stresszhatások jelenlétében egyaránt.

Ilyen jellegủ méréseket számtalan zöldségfajnál végeztek, többek között paradicsom, paprika, uborka, stb. esetében.

Vizsgálatunk célja az volt, hogy üzemi üvegházi termesztési körülmények között összehasonlítsuk két hajtatott paradicsom fajtatípus és ezen belül három fajta (2 snack és 1 nagy bogyójú fajta) nettó fotoszintézisének fényválaszgörbéjét. Ezen túlmenően a két snack paradicsomfajta nettó fotoszintézisének napi menetét is megmértük.

\section{Anyag és módszer}

A méréseket három paradicsom fajtával az Árpád Agrár Zrt. szegvári telephelyén, üvegházi körülmények között végeztük, talaj nélküli termesztési módnál.

A két snack típusú fajta az Enza 1114 és Sweetelle, a nagybogyójú pedig a Multicia fajta volt.

A növényeket 2019. december 4-én ültették ki kókuszrost közegbe, így az állomány a mérések idején (2020. szeptember 24-én és október 8-án) 9-10 hónapos volt. Megmértük a három fajta fényválaszgörbéjét PAR 0-1600 $\mu \mathrm{mol} \mathrm{m}^{-2} \mathrm{~s}^{-1}$ fotonfluxus sürüség között. 0-tól 500-ig 50-es léptékkel, majd 800,1200, 1600 értéken mértünk. Az indulási sötét légzést 15 perc sötétadaptációt követően mértük meg, és az első fényfokozatban $\left(50 \mu \mathrm{mol} \mathrm{m} \mathrm{m}^{-2} \mathrm{~s}^{-1} \mathrm{PAR}\right) 5$ perc megvilágítás után történt a mérés. A méréseinket $25{ }^{\circ} \mathrm{C}$-os levélkamrában, $400 \mathrm{ppm} \mathrm{CO}_{2}$-nál és $70-75 \%$-os relatív páratartalom mellett végeztük, a növény felső részén, az első kifejlett levélen. A mérésekhez Walz gyártmányú GFS-3000típusú infravörös gázelemző müszer állt rendelkezésünkre (1. ábra). 


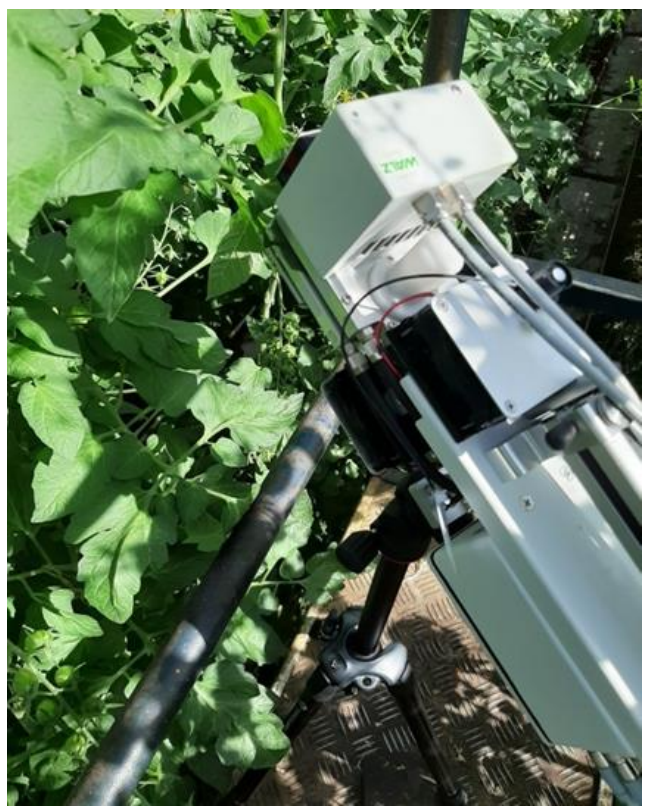

1.ábra Walz gyártmányú GFS-3000 fotoszintézis mérő

Az állománysürüség $2,8 \mathrm{db} / \mathrm{m}^{2}$ volt az indulásnál, majd ezt besürítették $4,66 \mathrm{db} / \mathrm{m}^{2}$-re.Ezen kívül PTM-50-es automata nettó fotoszintézis mérővel (2. ábra) is méréseket folytattunk a két snack fajtánál, 12 napon keresztül.

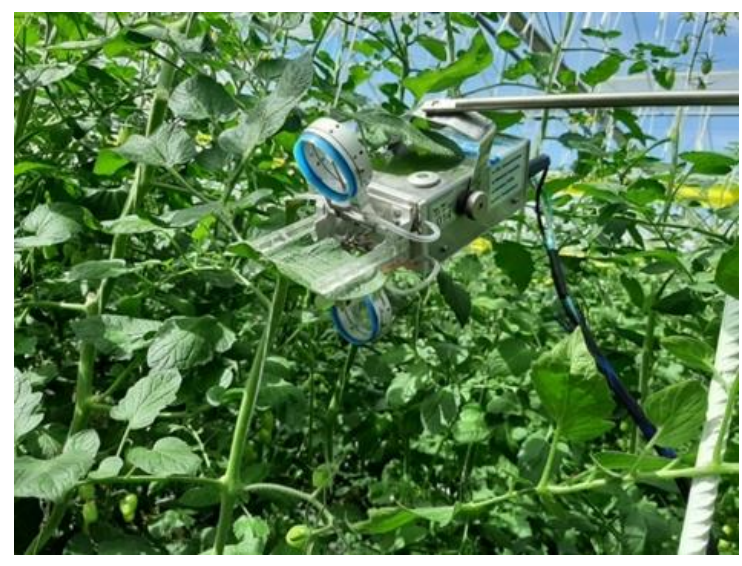

\section{2.ábra PTM-50-es automata fotoszintézis mérő levélkamrája}

\section{Eredmények}

A fényválaszgörbe mérést két időpontban végeztük. Az első, szeptember 24-i megfigyelésnél két snack paradicsomfajtán mértünk, s a kapott eredményeket a 3. ábrán láthatjuk. 


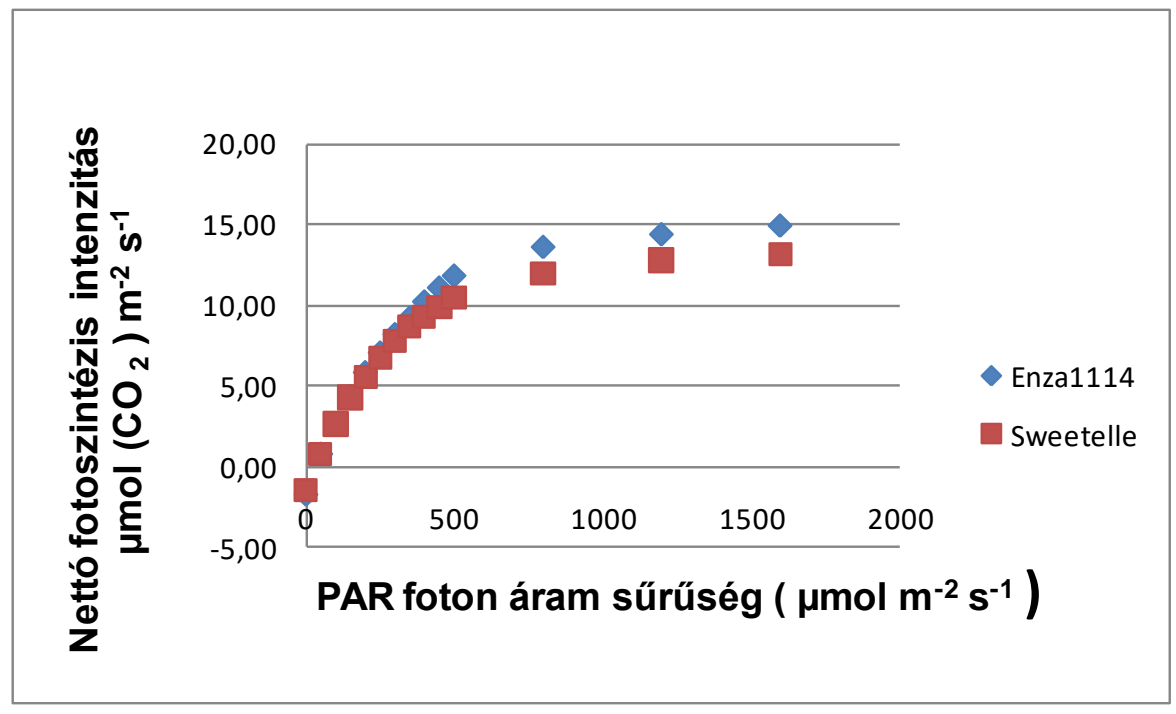

3. ábra Két snack paradicsomfajta fény válaszgörbéje $0-1600 \mu \mathrm{mol} \mathrm{m}^{-2} \mathrm{~s}^{-1} P A R$ fotonfluxus sürüségnél (Szegvár 2020.09.24.)

A két fajta nettó fotoszintézis intenzitás maximuma 13,2 , illetve $14,99 \mu \mathrm{mol}\left(\mathrm{CO}_{2}\right) \mathrm{m}^{-2} \mathrm{~s}^{-1}$ volt és az Enza1114 fajtánál volt a 13,6\%-kal nagyobb érték. A nettó fotoszintézis mellett mértük a két fajta sztóma konduktanciáját is (4. ábra).

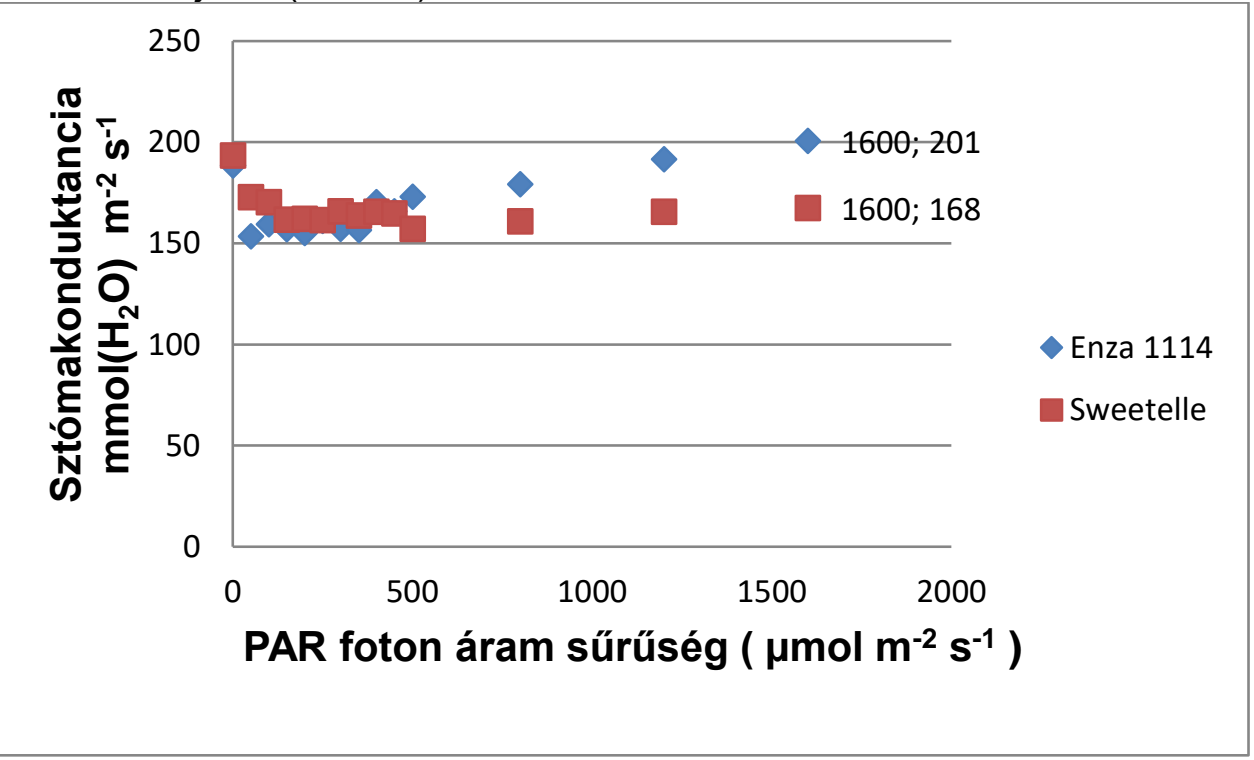

4. ábra Két snack paradicsomfajta sztómakonduktancia értékének változása a PAR fotonfluxus sürüség függvényében(Szegvár 2020.09.24.)

A nyitottabb sztómákat jelző konduktancia érték az Enza fajtánál 19,6\%-kal volt nagyobb. Ez adhat magyarázatot a nagyobb fotoszintézis intenzitásra, mivel az egyéb értékek (levélhőmérséklet, $\mathrm{CO}_{2}$-szint, sugárzás intenzitás, relatív páratartalom) megegyeztek a két fajtánál. Október 8-án megismételtük a fényválaszgörbe felvételét, s ekkor a mérés még egy nagy bogyójú fajtával (Multician) is kiegészült (5. ábra). 


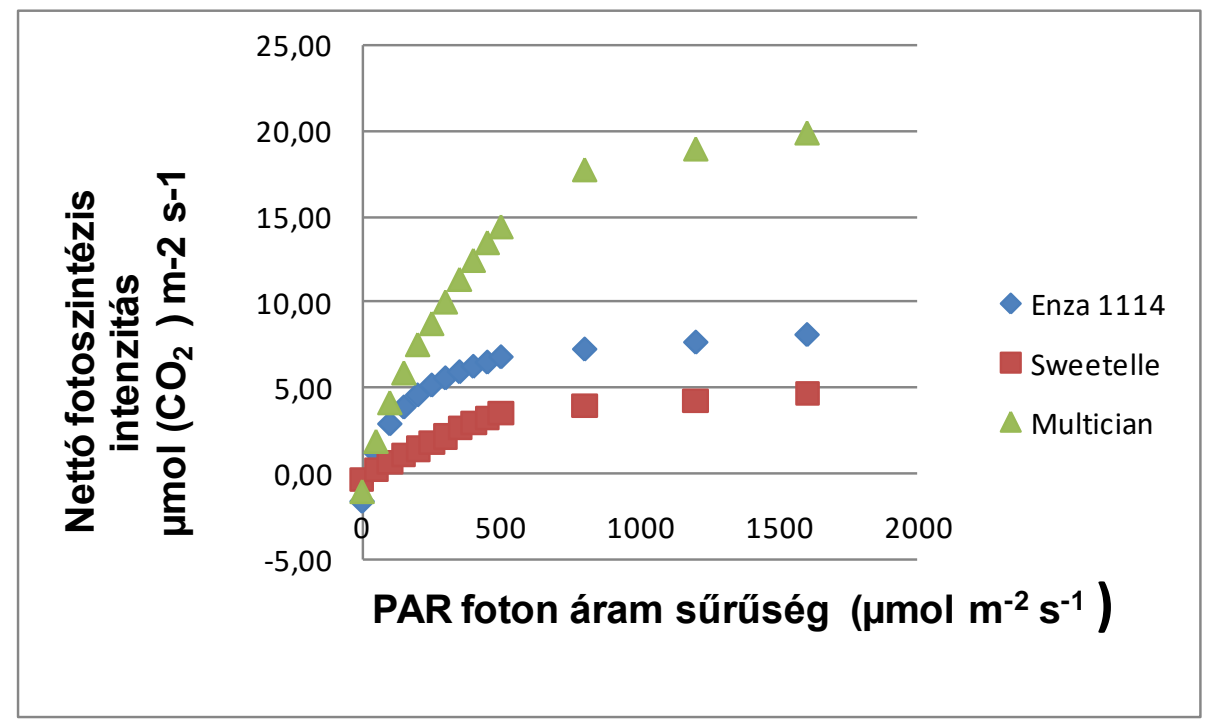

5. ábra Három paradicsomfajta nettó fotoszintézis fényválaszgörbéje (Szegvár 2020.10.08.)

A két snack fajtánál hasonló tendencia volt megfigyelhető, mint a korábbi mérésnél, de itt a különbség 79\%-os volt az Enza 1114 fajta javára, azaz ennél a fajtánál sokkal nagyobb maximális értéket mértünk. A nagy bogyójú, Multicia fajta értéke pedig az Enza 1114 fajtához képest 2,46 szoros volt. A sztómakonduktancia mérési eredmények a 6. ábrán láthatók.

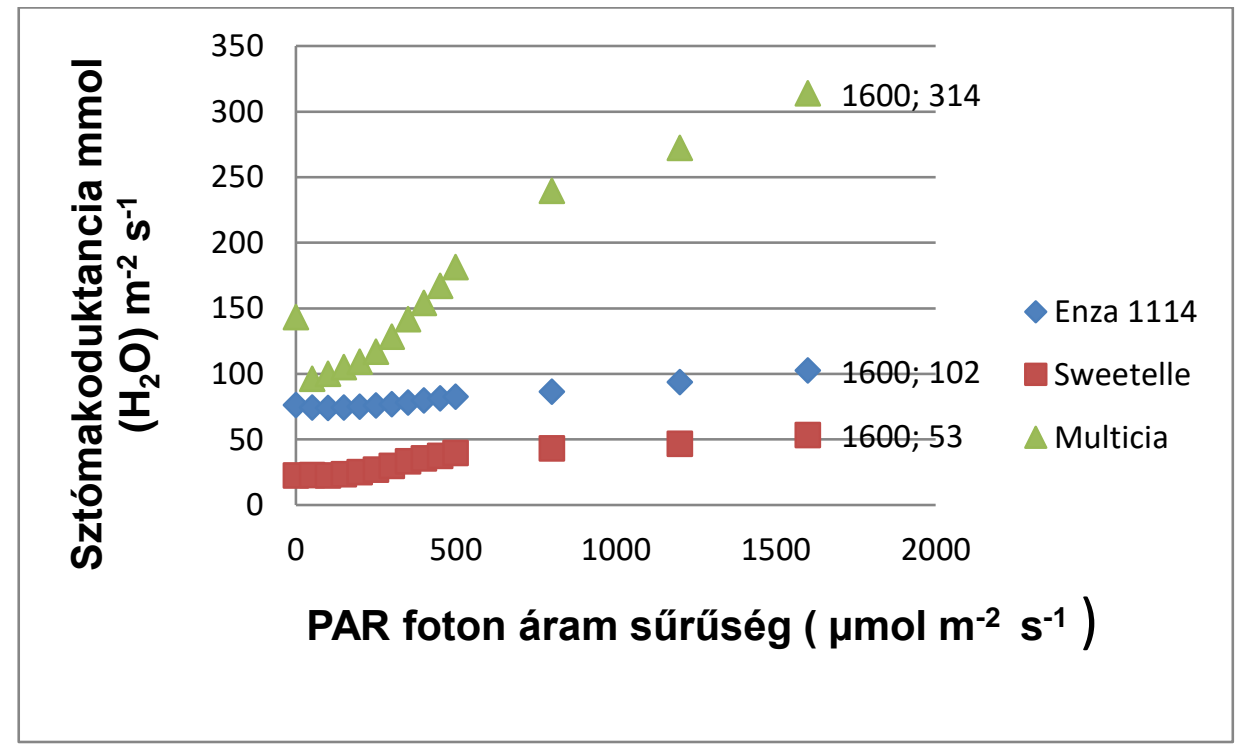

6. ábra Három paradicsomfajta sztómakonduktancia változása PAR fotonfluxus sürüség függvényében (Szegvár 2020.10.08.)

A sztómakonduktancia értékek tendenciájukban a szeptemberi méréshez hasonlót mutattak. Az Enza fajta értéke közel kétszerese volt a Sweetelle fajtának. A nagy bogyójú Multicia fajta pedig több mint háromszoros értéket mutatott az Enza fajtához képest. Megállapítható, hogy a sztómanyitottság pozitív korrelációt mutatott a nettó fotoszintézis értékekkel. 
A PTM-50-es müszer 12 napi méréséböl egy jellegzetes napot választottunk, október másodikát mutatja a 7 . ábra.

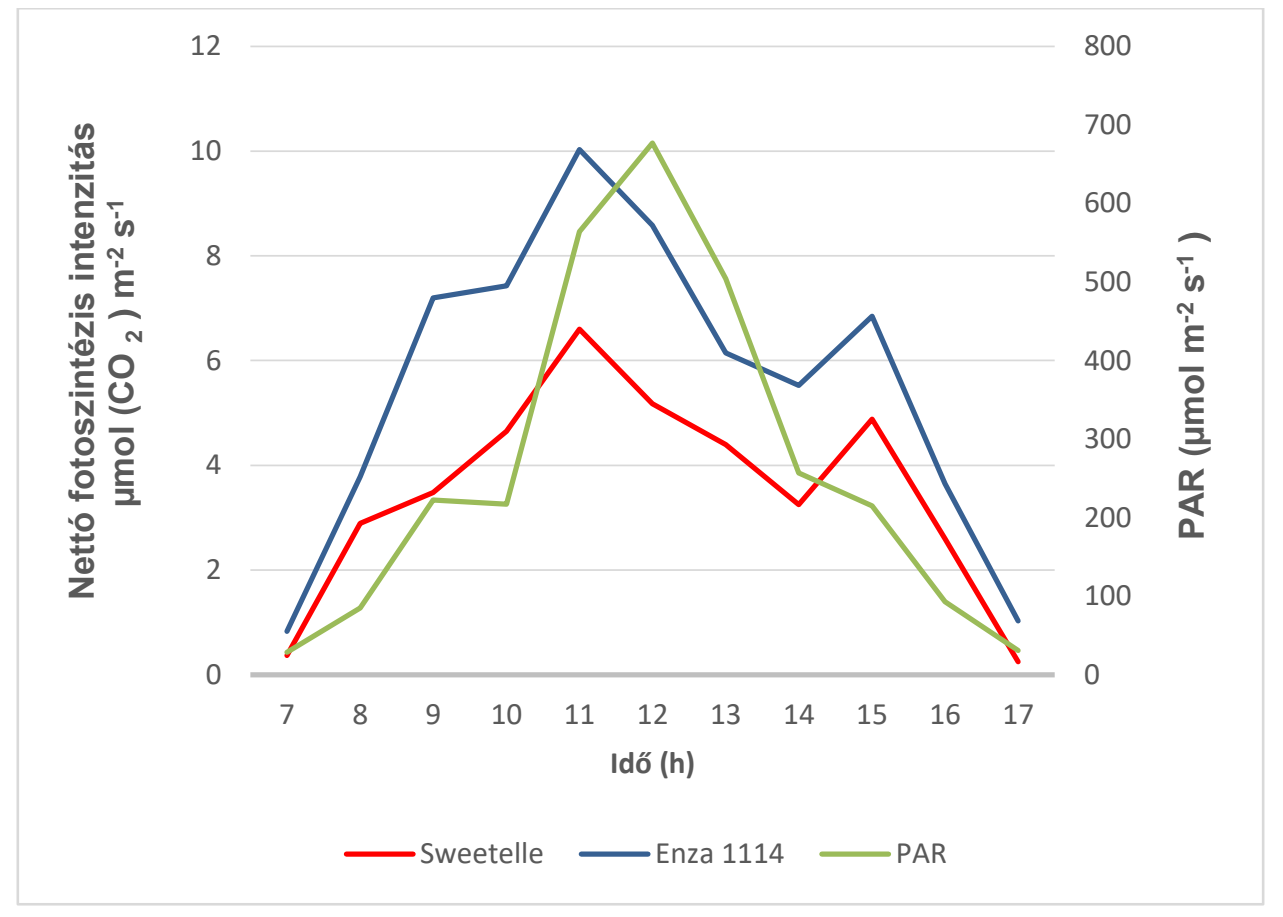

\section{7. ábra A nettó fotoszintézis és a PAR napi menete 2 snack paradicsomfajtánál (Szegvár} 2020.10.02.)

Ezen a napon az Enza fajta maximuma 10,18, míg a Sweetelle fajta maximuma 6,6 volt, a különbség mintegy $35 \%$-os volt az Enza fajta javára. A napi sugárzás maximuma 708 PAR $(\mu \mathrm{mol} \mathrm{m}$ ${ }^{2} S^{-1}$ ) volt. Jól megfigyelhető volt egy 14 óra körüli ún. déli depresszió is.

A fajták szedési eredményét is összevetettük a levelek fajlagos nettó fotoszintézis értékeivel. Az október 05-ig leszedett összes termésmennyiség a 2 snack fajta esetében:

- az Enza 1114 fajtánál $26,43 \mathrm{~kg} / \mathrm{m}^{2}$,a Sweetelle fajtánál 22,15 kg/m² volt. Itt a különbség 19,3 \%-os volt. A nagy bogyójú fajtánál a termésátlag $55,6 \mathrm{~kg} / \mathrm{m}^{2}$ volt. Ez 2,1 szerese a jobbik snack fajta termésátlagának. Ez hasonló tendenciát mutat, mint a nettó fotoszintézis intenzitásnál tapasztaltak.

\section{Következtetések, javaslatok}

Az alkalmazott müszeres növényélettani mérések a kapott eredmények alapján alkalmasnak látszanak a termesztésben lévő paradicsomfajták és fajtatípusok jellemzésére. Kellő számú, célzott mérés esetén - további, fix telepítésü biofizikai szenzorok bevetésével - az egyes fajták technológiai optimalizálására is alkalmazhatjuk a bemutatott müszeres növényélettani méréstechnikákat.

Ennek tükrében, a vizsgálatok folytatása feltétlenül indokolt, mégpedig a termesztési ciklus minden szakaszában.

\section{Köszönetnyilvánítás}

A szerzők köszönetet mondanak a 2018-1.3.1.-VKE-2018-00044. számú, „Stressztoleráns zöldségfajták nemesítése növényfiziológiai mérések segítségével" című pályázati támogatásért a kísérletek megvalósítása során. 


\section{Irodalomjegyzék}

[1] Ayari O.,Dorais, M.,Gosselin,A. (2000): Daily Variations of Photosynthetic Efficiency of Greenhouse Tomato Plant during Winter and Spring. J. Amer. Soc.Hort. Sci.125(2) 235-241p. https://doi.org/10.21273/JASHS.125.2.235

[2] Bhatt RM and Srinivasa Rao NK (1997) Growth and photosynthesis in bell-pepper as affected by sink manipulation. Biol. Plant., Short Communication, 39, 437-439 p. https://doi.org/10.1023/A:1001096614139

[3] Chengyao et al.: (2017):Photosynthesis, plant growth, and fruit production of single-truss tomato improves with supplementallightingprovidedfromunderneathorwithintheinnercanopy.ScientiaHorticultureaaugustus 2017 221-229p. http://dx.doi.org/10.1016/j.scienta.2017.04.026

[4] deMelo HF, de Souza ER, Duarte HHF,Cunha JC, and Santos HRB (2017) Gas exchange and photosynthetic pigments in bell pepper irrigated with saline water. Revista Brasileira de Engenharia Agrícola e Ambiental, 21, 3843. http://dx.doi.org/10.1590/1807-1929/agriambi.v21n1p38-43

[5] Erwin J, Hussein T, and Baumler DJ (2019) Pepper Photosynthesis, Stomatal Conductance, Transpiration, and Water Use Efficiency Differ with Variety, Indigenous Habitat, and Species of Origin. HortSci.,54,1662-1666 p. https://doi.org/10.21273/HORTSCl13871-19

[6] Espinosa-Calderon A, Torres-Pacheco I, Padilla-Medina JA, Chavaro-Ortiz RM, Xoconostle-Cazares B, GomezSilva L, Ruiz-Medrano R, Guevara-Gonzalez RG (2012) Relationship between leaf temperature and photosynthetic carbon in Capsicum annuum L. in controlled climates. J. Sci. Ind. Res.,71, 528-533 p.

[7] He Y, Wu Z, Wang W, Ye B-C, Thang F, Liu X (2019):Different Responses of capsicum annum L. Root and Shoot to Salt sSress with Pseudomonas putidaRs-198 Inoculation. J. Plant Growth Reg.,38, 799-811 p. https://doi.org/10.1007/s00344-018-9891-y

[8] Kim. et. al.: (2017): Ray-Sweet Pepper (Capsicum annum L.) Canopy Photosynthesis Modeling Using 3D Plant Architecture and Light Ray-Tracing. Plant Science September 2016. https://doi.org/10.3389/fpls.2016.01321

[9] Nabeshima S, Yasutake D, and Kitano M (2019) Hybrid Vigor Induced by Cross-breeding Enhances Canopy Photosynthesis and Fruit Yield of Japanese Sweet Pepper. Environ. Control Biol., 57, 29-38 p. https://doi.org/10.2525/ecb.57.29

[10] Nederhoff EM and Vegter JG (1994) Canopy Photosynthesis of Tomato, Cucumber and Sweet Pepper in Greenhouses: Measurements Compared to Models. Ann. Bot.73, 421-427 p. https://doi.org/10.1006/anbo.1994.1052

[11] Rosado-Souza L, Scossa F, Chaves IS, Kleessen S, Salvador LFD, Milagre JC, Finger F, Bhering LL, Sulpice R, Araújo WL, Nikoloski Z, Fernie AR, and Nunes-Nesi A (2015) Exploring natural variation of photosynthetic, primary metabolism and growth parameters in a large panel of Capsicum chinense accessions. Planta, 242, 677-691 p. https://doi.org/10.1007/s00425-015-2332-2

[12] Xiao-Cong et. al.: (2019):Coordination between vapor pressure deficit and CO2ontheregulation of photosynthesis and productivity in greenhouse tomato production .Scietific Report (2019) 9:8700. https://doi.org/10.1038/s41598$\underline{019-45232-w}$ 